\title{
Benign familial neonatal epilepsy
}

\author{
INSERM
}

\section{Source}

INSERM. (1999). Orphanet: an online rare disease and orphan drug data base. Benign familial neonatal epilepsy. ORPHA:1949

Benign familial neonatal epilepsy (BFNE) is a rare genetic epilepsy syndrome characterized by the occurrence of afebrile seizures in otherwise healthy newborns with onset in the first few days of life. 